Tropical Journal of Pharmaceutical Research March 2017; 16 (3): 621-625

ISSN: $1596-5996$ (print); 1596-9827 (electronic)

(C) Pharmacotherapy Group, Faculty of Pharmacy, University of Benin, Benin City, 300001 Nigeria.

All rights reserved.

Available online at http://www.tjpr.org

Original Research Article

http://dx.doi.org/10.4314/tjpr.v16i3.17

\title{
Chemical composition of essential oil of exudates of Dryobalanops aromatica
}

\author{
Tian-Xin Le ${ }^{1}$, Anthony Siong-Hock $\mathrm{Ho}^{2}$, Siau-Hui Mah ${ }^{2}$, Tin-Wui Wong ${ }^{3}$, Hean- \\ Chooi Ong ${ }^{4}$, Patrick Heng-Meng Loh ${ }^{5,6}$ and Yang-Mooi Lim ${ }^{1 *}$ \\ ${ }^{1}$ Department of Pre-Clinical Sciences, Faculty of Medicine and Health Sciences, Universiti Tunku Abdul Rahman, Lot PT \\ 21144, Jalan Sungai Long, Bandar Sungai Long, 43000 Kajang, Selangor, '2 School of Biosciences, Taylor's University, \\ Lakeside Campus, No. 1 Jalan Taylor's, 47500 Subang Jaya, Selangor, ${ }^{3}$ Department of Pharmaceutics, Faculty of Pharmacy, \\ University Teknologi MARA, Puncak Alam Campus, Bandar Puncak Alam, 42300 Selangor, ${ }^{4}$ Institute of Biological Sciences, \\ Faculty of Science, University of Malaya, 50603 Kuala Lumpur, Malaysia, ${ }^{5}$ Faculty of Sustainability, Environmental \& Life \\ Sciences, Murdoch University, Loneragan Building, Perth, Australia 6150, ${ }^{6}$ School of Science \& Technology, SIM University, \\ 461 Clementi Road, Singapore 599491
}

*For correspondence: Email: ymlim@utar.edu.my; Tel: +60390860288

Revised accepted: 10 June 2016

\begin{abstract}
Purpose: To identify the chemical composition of essential oil from the exudates of Dryobalanops aromatica from Malaysia.

Methods: Exudate was collected from D. aromatica and subjected to fractional distillation to obtain essential oil. Gas chromatography-mass spectrometry (GC-MS) was used to characterize the composition of the isolated essential oil.

Results: The yield of essential oil was $7.58 \%$, with the highest yield $(3.24 \%)$ within the first $2 h$ of fractional distillation. Thirty compounds which accounted for $97.56 \%$ of essential oil composition were identified. These include sesquiterpenes (46.87\%), monoterpenes (31.05\%), oxygenated monoterpenes (16.76\%) and oxygenated sesquiterpenes (2.13\%). Borneol accounted for $0.74 \%$ of the essential oil.

Conclusion: Essential oil from the exudates of D. aromatica contains terpenoid compounds and borneol.
\end{abstract}

Keywords: Dryobalanops aromatica, exudate, fractional distillation, essential oil, GS-MS, borneol

Tropical Journal of Pharmaceutical Research is indexed by Science Citation Index (SciSearch), Scopus, International Pharmaceutical Abstract, Chemical Abstracts, Embase, Index Copernicus, EBSCO, African Index Medicus, JournalSeek, Journal Citation Reports/Science Edition, Directory of Open Access Journals (DOAJ), African Journal Online, Bioline International, Open-J-Gate and Pharmacy Abstracts

\section{INTRODUCTION}

D. aromatica is a large tropical rainforest species recognised for its valuable timber, locally known as kapur, Borneo camphor, camphor tree, or Sumatran camphor. It can grow up to $60 \mathrm{~m}$ in height, with girth of $9 \mathrm{~m}$ [1]. The tree which has been classified as critically endangered species, is found only in Malaysian Peninsular, Borneo and Sumatra [2]. The genus Dryobalanops belongs to the Dipterocarpaceae family and is one of the two species that can be found in
Peninsular Malaysia, the other being $D$. oblongifolia [2].

Although ancient Chinese literature reported that $D$. aromatica is the premium source of borneol, there are no scientific reports on the isolation of borneol from this plant $[3,4]$. Researches on $D$. aromatica have so far focused mainly on the tree bark. Moreover, there is limited information on the complete chemical profiling of the extracts or essential oil isolated from the exudates of $D$. aromatica. 
Borneol is an expensive compound used in Chinese and Western medicine for many years. It is an essential ingredient in 65 traditional Chinese medicines [5]. In recent years, natural borneol has been isolated from the leaves of Cinnamomum glanduliferum [6], Cinnamomum camphora [7] and Cinnamomum burmannii [8]. Borneol can also be synthesized from turpentine oil or camphor as Borneolum syntheticum in the form of DL-borneol and iso-borneol. However, synthetic borneol has been shown to exert some toxic effects that due to the presence of isoborneol and camphor [9]. This makes natural borneol especially D-borneol the safer ingredient for medicinal purposes. However, due to high demand and high production cost, natural borneol is in short supply [10].

In view of the high distribution of $D$. aromatica in Malaysian Peninsular and the potential of $D$. aromatica as an alternative source of natural borneol, this study was conducted to determine the presence of borneol and other chemical composition in the essential oil extracted from the exudates of $D$. aromatica. Further studies were biological activities of the essential oil and the isolated pure compounds, particularly on anticancer properties, namely, cytotoxic and antitumor promoting activities.

\section{EXPERIMENTAL}

\section{Plant material}

Exudates of $D$. aromatica, obtained either from natural exudates from the tree or by mechanical incision, were collected from Commonwealth Forest Reserve, Selangor, Malaysia. Plant identification and authentication were done by Professor Dr Ong Hean Chooi from University of Malaya, Malaysia and a voucher specimen (UTAR/LTX01/12) was deposited at herbarium of Universiti of Tunku Abdul Rahman.

\section{Fractional distillation of exudates}

Exudates were subjected to fractional distillation in double distilled water for $2 \mathrm{~h}$ at $80-90^{\circ} \mathrm{C}$. After cooling at room temperature for $2 \mathrm{~h}$, the essential oil and distilled water were separated and this was followed by another cycle of fractional distillation. The process was repeated until the yield of essential oil became minimal. The essential oil was then pooled and stored at $20^{\circ} \mathrm{C}$.

\section{GC-MS analysis}

The essential oil was analyzed by Agilent 7890A/5975C GC-MS system equipped with
HP5ms stationary phase column $(30 \mathrm{~m} \times 0.25 \mathrm{~mm}$ internal diameter $\times 0.25 \mu \mathrm{m}$ film thickness) composed of $5 \%$ phenylpolysiloxane/95\% dimethylpolysiloxane. Helium was used as carrier gas and programmed at a flow rate of $1.0 \mathrm{ml} / \mathrm{min}$. The sample injection volume was $1 \mu \mathrm{L}$, with split ratio of 1:10. The initial oven temperature was programmed at $80{ }^{\circ} \mathrm{C}$, held for $5 \mathrm{~min}$, then increased to $140^{\circ} \mathrm{C}$ at $10^{\circ} \mathrm{C} / \mathrm{min}$, held for 0.5 min and increased to $300{ }^{\circ} \mathrm{C}$ at $30{ }^{\circ} \mathrm{C} / \mathrm{min}$ with final hold for $2 \mathrm{~min}$. Electron ionization system with ionization energy of $70 \mathrm{eV}$ was used. Injector and MS transfer line temperatures were set at 230 and $280{ }^{\circ} \mathrm{C}$, respectively. The MS system was operated in scan mode with a mass range of $50-400 \mathrm{~m} / z$. Identification of compounds were achieved through the determination of retention indices $(\mathrm{RI})$ with reference to a homologous series of $n$-alkanes $\left(\mathrm{C}_{8}-\mathrm{C}_{20}\right)$ and by NIST mass spectrum library matching.

\section{RESULTS}

\section{Yield of essential oil}

Through fractional distillation, different compounds were extracted based on their volatility. Less volatile compounds were separated first followed by more volatile compounds. The average essential oil obtained from the exudates of $D$. aromatica was $7.58 \%$ over $28 \mathrm{~h}$ of fractional distillation. The higest yield of essential oil was at the first $2 \mathrm{~h}$ of fractional distillation, which was $3.24 \%$; and the yield decreased with increasing number of cycles of fractional distillation.

\section{Essential oil composition}

Thirty compounds, which accounted for $97.56 \%$ of essential oil composition from the exudates of $D$. aromatica were identified using GC-MS analysis (Figure 1; Table 1). The essential oil consisted of monoterpenes and sesquiterpenes; and the major compounds identified, in order of abundance, were $\beta$-caryophyllene (31.76\%), $\alpha$ pinene $(21.49 \%)$, $\alpha$-caryophyllene $(13.50 \%)$, terpinen-4-ol $(8.58 \%)$ and $\alpha$-terpineol $(5.89 \%)$. In addition, $0.74 \%$ of borneol was detected.

\section{DISCUSSION}

Borneol is a bicyclic monoterpene that has been used in traditional Chinese medicine for many years as a premium ingredient for treating heart disease, coma and respiratory problems; indigestion and pain relief [11]. In this study, borneol was detected in the essential oil of $D$. aromatica at $0.74 \%$. 


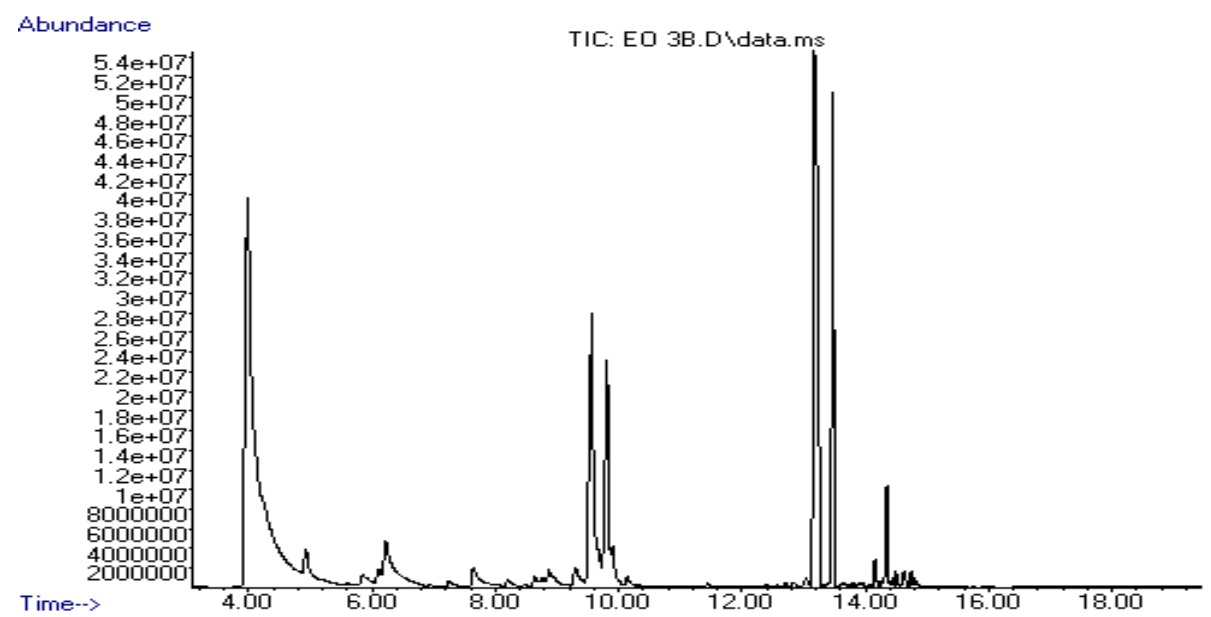

Figure 1: Total ion chromatogram of essential oil extracted from the exudates of $D$. aromatica by GC-MS analysis

Table 1: Chemical composition of essential oil extracted from the exudates of $D$. aromatica

\begin{tabular}{|c|c|c|c|c|c|c|c|c|}
\hline \multirow{2}{*}{ No. } & \multirow{2}{*}{ Compound } & \multirow{2}{*}{$\begin{array}{l}\text { Molecular } \\
\text { formula }\end{array}$} & \multirow{2}{*}{$\underset{(\min )}{R T}$} & \multirow{2}{*}{$\mathbf{R \mathbf { I } ^ { \mathbf { a } }}$} & \multicolumn{3}{|c|}{ Sample $(n=3)$} & \multirow{2}{*}{ Mean \pm SD (\%) } \\
\hline & & & & & 1 & 2 & 3 & \\
\hline 1 & $\alpha$-pinene & $\mathrm{C}_{10} \mathrm{H}_{16}$ & 3.983 & 934 & 36.73 & 16.96 & 10.78 & $21.49 \pm 13.56$ \\
\hline 2 & $\beta$-pinene & $\mathrm{C}_{10} \mathrm{H}_{16}$ & 4.928 & 979 & 1.42 & 0.84 & 0.56 & $0.94 \pm 0.44$ \\
\hline 3 & $\alpha$-phellandrene & $\mathrm{C}_{10} \mathrm{H}_{16}$ & 5.597 & 1009 & - & 0.72 & 1.24 & $0.65 \pm 0.62$ \\
\hline 4 & 1,4-cineole & $\mathrm{C}_{10} \mathrm{H}_{18} \mathrm{O}$ & 5.852 & 1019 & 0.64 & - & - & $0.21 \pm 0.37$ \\
\hline 5 & m-cymene & $\mathrm{C}_{10} \mathrm{H}_{14}$ & 6.100 & 1029 & 0.55 & 0.27 & 0.26 & $0.36 \pm 0.16$ \\
\hline 6 & D-limonene & $\mathrm{C}_{10} \mathrm{H}_{16}$ & 6.224 & 1034 & 4.15 & - & - & $1.38 \pm 2.40$ \\
\hline 7 & $\beta$-myrcene & $\mathrm{C}_{10} \mathrm{H}_{16}$ & 6.231 & 1035 & - & 5.55 & - & $1.85 \pm 3.20$ \\
\hline 8 & $Y$-terpinene & $\mathrm{C}_{10} \mathrm{H}_{16}$ & 6.934 & 1063 & - & 0.79 & 9.73 & $3.51 \pm 5.40$ \\
\hline 9 & (+)-4-carene & $\mathrm{C}_{10} \mathrm{H}_{16}$ & 7.638 & 1092 & - & 0.93 & 0.41 & $0.45 \pm 0.47$ \\
\hline 10 & (+)-2-carene & $\mathrm{C}_{10} \mathrm{H}_{16}$ & 7.652 & 1093 & 1.27 & - & - & $0.42 \pm 0.73$ \\
\hline 11 & (+)-fenchol & $\mathrm{C}_{10} \mathrm{H}_{18} \mathrm{O}$ & 8.203 & 1118 & 0.28 & - & - & $0.09 \pm 0.16$ \\
\hline 12 & terpinen-1-ol & $\mathrm{C}_{10} \mathrm{H}_{18} \mathrm{O}$ & 8.631 & 1139 & 0.36 & - & - & $0.12 \pm 0.21$ \\
\hline 13 & (-)-camphor & $\mathrm{C}_{10} \mathrm{H}_{16} \mathrm{O}$ & 8.872 & 1151 & 1.03 & 0.99 & 1.14 & $1.05 \pm 0.08$ \\
\hline 14 & Borneol & $\mathrm{C}_{10} \mathrm{H}_{18} \mathrm{O}$ & 9.300 & 1172 & 0.84 & 0.79 & 0.58 & $0.74 \pm 0.14$ \\
\hline 15 & terpinen-4-ol & $\mathrm{C}_{10} \mathrm{H}_{18} \mathrm{O}$ & 9.562 & 1185 & 10.64 & 5.81 & 9.29 & $8.58 \pm 2.49$ \\
\hline 16 & $\alpha$-terpineol & $\mathrm{C}_{10} \mathrm{H}_{18} \mathrm{O}$ & 9.899 & 1202 & 7.96 & 5.89 & 3.81 & $5.89 \pm 2.08$ \\
\hline 17 & Verbenone & $\mathrm{C}_{10} \mathrm{H}_{14} \mathrm{O}$ & 10.141 & 1216 & 0.25 & - & - & $0.08 \pm 0.14$ \\
\hline 18 & bornyl acetate & $\mathrm{C}_{12} \mathrm{H}_{20} \mathrm{O}_{2}$ & 11.444 & 1290 & - & 0.76 & 0.47 & $0.41 \pm 0.38$ \\
\hline 19 & Copaene & $\mathrm{C}_{15} \mathrm{H}_{24}$ & 12.713 & 1388 & 0.1 & 0.15 & - & $0.08 \pm 0.08$ \\
\hline 20 & $\alpha$-farnesene & $\mathrm{C}_{15} \mathrm{H}_{24}$ & 12.816 & 1397 & 0.07 & - & - & $0.02 \pm 0.04$ \\
\hline 21 & $(-)-\beta$-elemene & $\mathrm{C}_{15} \mathrm{H}_{24}$ & 12.864 & 1401 & - & 0.47 & 0.37 & $0.28 \pm 0.25$ \\
\hline 22 & isocaryophillene & $\mathrm{C}_{15} \mathrm{H}_{24}$ & 13.044 & 1422 & 0.28 & - & - & $0.09 \pm 0.16$ \\
\hline 23 & $\beta$-caryophyllene & $\mathrm{C}_{15} \mathrm{H}_{24}$ & 13.182 & 1439 & 21.23 & 37.96 & 36.09 & $31.76 \pm 9.17$ \\
\hline 24 & $\alpha$-caryophyllene & $\mathrm{C}_{15} \mathrm{H}_{24}$ & 13.478 & 1475 & 8.40 & 16.31 & 15.78 & $13.50 \pm 4.42$ \\
\hline 25 & Curcumene & $\mathrm{C}_{15} \mathrm{H}_{22}$ & 13.616 & 1492 & - & - & 0.87 & $0.29 \pm 0.50$ \\
\hline 26 & $(E)-\beta$-famesene & $\mathrm{C}_{15} \mathrm{H}_{24}$ & 13.802 & 1519 & - & 0.94 & 2.22 & $1.05 \pm 1.11$ \\
\hline 27 & $\alpha$-bergamotene & $\mathrm{C}_{15} \mathrm{H}_{24}$ & 13.864 & 1529 & - & - & 0.24 & $0.08 \pm 0.14$ \\
\hline 28 & cis- $\alpha$-bisabolene & $\mathrm{C}_{15} \mathrm{H}_{24}$ & 14.023 & 1554 & - & - & 0.11 & $0.04 \pm 0.06$ \\
\hline 29 & caryophyllene oxide & $\mathrm{C}_{15} \mathrm{H}_{24} \mathrm{O}$ & 14.354 & 1608 & 1.51 & 0.37 & 3.99 & $1.96 \pm 1.85$ \\
\hline 30 & humulene epoxide & $\mathrm{C}_{15} \mathrm{H}_{24} \mathrm{O}$ & 14.505 & 1638 & - & - & 0.52 & $0.17 \pm 0.30$ \\
\hline \multicolumn{2}{|c|}{ Monoterpene hydrocarbons } & & - & - & 44.12 & 26.06 & 22.98 & $31.05 \pm 11.42$ \\
\hline \multicolumn{2}{|c|}{ Oxygenated monoterpenes } & & - & - & 22.00 & 13.48 & 14.82 & $16.76 \pm 4.58$ \\
\hline \multicolumn{2}{|c|}{ Sesquiterpene hydrocarbons } & & - & - & 30.08 & 55.83 & 54.81 & $46.87 \pm 14.58$ \\
\hline \multicolumn{2}{|c|}{ Oxygenated sesquiterpenes } & & - & - & 1.51 & 0.37 & 4.51 & $2.13 \pm 2.14$ \\
\hline \multicolumn{2}{|c|}{ Others } & & - & - & - & 0.76 & 1.34 & $0.70 \pm 0.67$ \\
\hline \multicolumn{2}{|c|}{ Total identified } & & - & - & 97.71 & 96.50 & 98.46 & 97.56 \\
\hline
\end{tabular}


The other compounds detected accounted for $81.22 \%$ of the total essential oil. This study reported for the first time on the presence of $\alpha$ pinene, terpinen-4-ol and $\alpha$-terpineol as the major components of essential oil from the exudates of $D$. aromatica. This study has identified some compounds not earlier reported by Huang and Lu [3]. These are $d$-borneol, $\alpha$ caryophyllene, $\beta$-elemene, $\beta$-caryophyllene, asiatic acid, dryobalanone, erythrodiol and hydroxy-dammarenone II. The synthesis of phytochemicals can be affected qualitatively or quantitatively in response to environmental conditions, geographical variation, genetic factors and evolution; or physiological variations such as type of plant material, pollinator activity cycle, organ development and mechanical or chemical injuries [12,13]. The differences observed in the chemical composition of essential oil between the present study and that of Huang and Lu might be due to geographical variation of plant species, which led to differences in environmental conditions.

The compounds detected in this study ( $d$ borneol, terpinen-4-ol, $\alpha$-terpineol, $\alpha$-pinene and caryophyllene) are terpenoid compounds well known for their anti-microbial, antiviral, antiinflammatory and cytotoxic effects [14-20].

\section{CONCLUSION}

Twenty-seven compounds have been identified from the essential oil from the exudates of $D$. aromatica. These terpenoid compounds have great potential in the pharmaceutical, perfumery, aroma-therapeutic, cosmetic, detergent and food industries.

\section{DECLARATIONS}

\section{Acknowledgement}

The authors would like to express their deepest gratitude to Eu Yan Sang International Ltd (Singapore) and Universiti Tunku Abdul Rahman for supporting and sponsoring this research (Vote number: 4380/000 and 6200/L62).

\section{Conflict of Interest}

No conflict of interest associated with this work.

\section{Contribution of Authors}

The authors declare that this work was done by the authors named in this article and all liabilities pertaining to claims relating to the content of this article will be borne by them.

\section{Open Access}

This is an Open Access article that uses a funding model which does not charge readers or their institutions for access and distributed under the terms of the Creative Commons Attribution License (http://creativecommons.org/licenses/by 14.0) and the Budapest Open Access Initiative (http://www.budapestopenaccessinitiative.org/rea d), which permit unrestricted use, distribution, and reproduction in any medium, provided the original work is properly credited.

\section{REFERENCES}

1. Gan KS, Choo T, Lim SC. Timber Notes - Medium Hardwoods I (Kapur, Kasai, Kelat, Keledang, Kempas). Timber Technology Centre (TTC), FRIM 1999; 11: 139258.

2. Ali RM, Koh MP, Michael M. Quantification of some components of the extractives of Dryobalanops aromatica obtained from different sources. J Tropl Forest Sci 1991; 3: 367-371.

3. Huang WD, Lu WQ. The research development of borneol. China Pharm 2008; 17: 64-66.

4. Park TJ, Park YS, Lee TG, Ha H, Kim KT. Inhibition of acetylcholine-mediated effects by borneol. Biochem Pharmacol 2003; 65: 83-90.

5. Su J, Chen J, Liao S, Li L, Zhu L, Chen L. Composition and biological activities of the essential oil extracted from a novel plant of Cinnamomum camphora Chvar. Borneol. J Med Plants Res 2012; 6: 3487-3494.

6. Song YF, Luo JL. Study on preparation of high-purity natural d-borneol. Chemistry and Industry of Forest Products 2003; 23: 11-14.

7. Liu T, Gong L, Guo Y, Ren $S$, Yang L, Xiao B, Pan $Q$. Determination of $d$-borneol in the different parts of Cinnamomum camphora by GC-MS. Zhongguo Zhong Yao Za Zhi 2009; 34: 1692-1694.

8. Chen $L, S u J, L i L, L i B, L i W$. A new source of natural $D$ borneol and its characteristic. J Med Plants Res 2011; 5 : 3440-3447.

9. Hu LM, Fan GW, Gao XM, Zhang PL. Comparison on the influence of natural borneol and synthetic borneol on gastric mucosal barrier in rats. J Tianjin University TCM 2005; 24: 123-125.

10. Su J, Chen L, Li B, Li L. Extraction and Composition Analysis of Volatile Components in Leaves of Cinnamomun burmannii B1. J Food Science 2010; 31: 399-401.

11. Buchbauer G, Jager W, Jirovetz L, Meyer F, Dietrich $H$. Effects of valerian root oil, borneol, isoborneol, bornyl acetate and isobornyl acetate on the motility of laboratory animals (mice) after inhalation. Pharmazie 1992; 47: 620-622.

12. Figueiredo AC, Barroso JG, Pedro LG, Scheffer JJC. Factors affecting secondary metabolite production in 
plants: volatile components and essential oils. Flavour Frag J 2008; 23: 213-226.

13. Jayanthy A, Prakash KU, Remashree AB. Seasonal and geographical variations in cellular characters and chemical contents in Desmodium gangeticum (L.) DC. an ayurvedic medicinal plant. Int $J$ Herbal Med 2013; 1: 34-37.

14. Almeida, JR, Souza GR, Silva JC, Saraiva SR, Júnior RG, Quintans Jde S, Barreto Rde S, Bonjardim LR, Cavalcanti SC, Junior LJ. Borneol, a bicyclic monoterpene alcohol, reduces nociceptive behavior and inflammatory response in mice. Sci World J 2013; 2013: 1-5.

15. Armaka M, Papanikolaou E, Sivropoulou A, Arsenakis M. Antiviral properties of isoborneol, a potent inhibitor of herpes simplex virus type 1. Antiviral Res 1999; 43: 7992.

16. Chen J, Li L, Su J, Li B, Chen T, Wong YS. Synergistic apoptosis-inducing effects on A375 human melanoma cells of natural borneol and curcumin. Plos One 2014; 9 : 1-9.

17. Legault J, Pichette A. Potentiating effect of $b$ caryophyllene on anticancer activity of a-humulene, isocaryophyllene and paclitaxel. J Pharm Pharmacol 2007; 59: 1643-1647.

18. Mondello F, Ricci M. Use of terpinen-4-ol as antimicrobial agent against bacteria of Legionella genus, Google Patents 2012.

19. Silva ACR, Lopes PM, Azevedo MMB, Costa DCM, Alviano CS, Alviano DS. Biological activities of a-pinene and B-pinene enantiomers. Molecules 2012; 17: 63056316.

20. Wu CS, Chen YJ, Chen JJW, Shieh JJ, Huang CH, Lin PS, Chang GC, Chang JHT, Lin CC. Terpinen-4-ol induces apoptosis in human non-small cell lung cancer in vitro and in vivo. Evid Based Complementary Altern Med 2011; 2012: 1-13. 